\title{
How Do Nurses Percept Workplace Incivility: A Cross-Sectional Study*
}

\section{Hemşireler Nezaketsizliği Nasıl Algılıyor: Kesitsel Bir Çalışma}

\author{
Ahmet Seven ${ }^{\oplus}$, Öznur Adadıoğlu ${ }^{\odot}$, Esin Danç ${ }^{\oplus}$
}

SHYD 2021;8(3):388-396

Cite as: Seven A, Adadıoğlu Ö, Danç E. How do nurses percept workplace incivility: A cross-sectional study. Journal of Health and Nursing Management. $2021 ; 8(3): 388-396$.

\begin{abstract}
Aim: This study aimed to determine how nurses perceive workplace incivility and the factors that affect their perceptions.

Method: The study was performed cross-sectionally with 163 nurses who agreed to participate. The data were collected using a questionnaire containing socio-demographic features and the Nursing Incivility Scale (NIS). Data analysis was performed in a computer environment using percentage, average, and nonparametric tests.

Results: The mean total score of the NIS of the nurses who participated in the study was $122.45 \pm 17.33$, and it was determined that the subscale means the score was $25.66 \pm 5.37$ (nurses in my service), $33.04 \pm 7.15$ (patients/visitors), $15.87 \pm 4,67$ (my first manager), 22.17 \pm 5.80 (doctors), and $25.69 \pm 4.65$ (general incivility). It was determined that there was a statistically significant difference between the variables "education, love the profession, the place where they spent their childhood, the way they worked, and the unit" and the mean and sub-dimension mean scores of the NIS $(p<0.05)$.

Conclusion: In the study, it was seen that the nurses perceived the workplace incivility in the middle level, education, love the profession, the way of working, and the unit variables affect the level of incivility perception.
\end{abstract}

Keywords: Incivility, nurse, perception.

\section{Öz}

Amaç: Bu çalışma, hemşirelerin nezaketsizliği nasıl algıladıklarını ve nezaketsizlik algı düzeylerini etkileyen etmenleri belirlemek amacıyla yapıldı.

Yöntem: Çalışma, kesitsel olarak çalışmaya katılmayı kabul eden 163 hemşire ile yapıldı. Veriler sosyo-demogrofik özellikleri içeren soru formu ve "Hemşirelikte Nezaketsizlik Ölçeği (HNÖ)" kullanılarak toplandı. Verilerin analizi bilgisayar ortamında; yüzdelik, ortalama ve nonparametrik testler kullanılarak yapıldı.

Bulgular: Çalışmaya katılan hemşirelerin HNÖ toplam puan ortalaması $122,45 \pm 17,33$ olup alt boyut puan ortalamaları sırasıyla 25,66 $\pm 5,37$ (servisimdeki hemşireler), 33,04 $\pm 7,15$ (hastalar/ ziyaretçiler), 15,87 $\pm 4,67$ (ilk yöneticim), 22,17 $\pm 5,80$ (doktorlar), 15,78 $\pm 3,11$ (genel nezaketsizlik

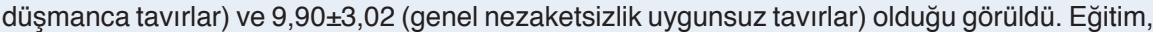
mesleği sevme, çocukluğunu geçirdiği yer, çalışma şekli ve çalışılan birim değişkenleri ile HNÖ toplam ve alt boyut puan ortalamaları arasında istatistiksel olarak anlamlı fark olduğu görüldü $(\mathrm{p}<0,05)$.

Sonuç: Çalışmada hemşirelerin genel olarak nezaketsizliği orta düzeyde algıladıkları, eğitim, mesleği sevme, çalışma şekli ve çalışılan birim değişkenlerinin nezaketsizlik algı düzeylerini etkilediği görüldü.

Anahtar Sözcükler: Nezaketsizlik, hemşire, algı.
Recieved / Gelis: 27.07.2021

Accepted / Kabul: 02.09.2021

Published Online / Online Yayın: 25.12.2021

Corresponding author/

Sorumlu yazar:

Ahmet Seven

Kahramanmaraş Sütçü İmam

Üniversitesi, Hemşirelik,

Kahramanmaraş, Türkiye

ahmetseven@ksu.edu.tr

ORCID: 0000-0002-2599-1918

Ö. Adadıoğlu 0000-0003-2804-4534 Sakarya Üniversitesi, Hemşirelik, Sakarya, Türkiye

E. Danç 0000-0001-7811-1868 Sakarya Yenikent Devlet Hastanesi, Hemşire, Sakarya, Türkiye

This study, 09-21 December 2019 held on the 6th. International, 17th National Nursing, as an oral presentation at the congress presented. 


\section{Introduction}

Civility is defined as being respectful, kind, gentle, attentive, and careful (Andersen, McAllister, Kardong-Edgren, Miller \& Churchouse, 2019; Clark, 2017). The concept of incivility, which is used as the opposite of civility, is the state of exhibiting actions such as not being subtle/gentle with others, disrespectful, careless, and rude (Andersen et al., 2019; Bambi, Guazzini, Felippis, Lucchini \& Rasero, 2017; Razzi \& Bianchi, 2019; Schoville \& Aebersold, 2020). People can face uncivil behavior in many environments (Guo, Qiu \& Gan, 2020). Especially in working environments, the incivility can reach serious dimensions (Green, 2019; Tricahyadinata, Hendryadi, Zainurossalamia \& Riadi, 2020).

Many institutions take precautions in order not to show uncivil behavior, improve interpersonal relations, and increase performance (Tricahyadinata et al., 2020). Today, despite the precautions taken in the workplace, it is observed that uncivil behaviors are gradually increasing (Guo et al., 2020; Samson-Mojares, Chin, Colvin \& Umadhay, 2019; Sleem \& Seada, 2017). This concept, which is defined as workplace discourtesy in the literature, is seen as the non-civilized, vulgar, and hurtful behavior of individuals in the work environment (Craft, Schivinski \& Wright, 2020; Irum, Ghosh \& Pandey, 2020; Razzi \& Bianchi, 2019; Samson-Mojares et al., 2019). Many factors are reported to be caused by workplace incivility (Irum et al., 2020). Among these factors are the discomfort between the subordinate and the superior, primarily due to violations of the workplace rules (Meier \& Semmer, 2013; Porath \& Pearson; 2012; Torkelson, Holm, Bäckström \& Schad, 2016). In addition, it is observed that it reveals the workplace discomfort due to factors such as the difference in corporate policies, the way of management, the way of working, and the characteristics of people (Irum et al., 2020; Pearson, 2010; Torkelson et al., 2016). Workplace incivility is more common, especially in institutions where people are in constant contact with each other and have a high circulation (Guo et al., 2020; Irum et al., 2020; Sleem \& Seada, 2017; Verasari \& Hamzah, 2019).

Health institutions are among the institutions where workplace incivility is seriously observed (Alquwez, 2020; SamsonMojares et al., 2019). Unkind behaviors displayed in the field of health can cause errors that may affect human life (Işıkay, 2019). It is seen that the uncivil behaviors seen in the field of health occur depending on the attitudes displayed by teammates, patients, and their relatives and clinical managers (Craft et al., 2020; Sleem \& Seada, 2017; Verasari \& Hamzah, 2019).

It was reported that the nurses are the most among the healthcare professionals that were exposed to discourtesy, in many studies conducted to determine workplace discourtesy (Bambi et al., 2017; Craft et al., 2020; Nikstaitis \& Simko, 2014; Razzi \& Bianchi, 2019). Nurses, who communicate more with the patients and their relatives, are constantly exposed to unkind behavior both inside and outside the team (Bolat \& Özmen, 2019; Craft et al., 2020). Unkind behaviors faced by nurses can affect the quality of care of patients (Alshehry, Alquwez, Almazan, Namis \& Cruz, 2019; El-Amrosy, Elkholy \& Elshall, 2019; Green, 2019; Işıkay, 2019; Woo \& Kim, 2020).

\section{Method}

Research Aim and Design: The current study in order to determine how the nurses, who are the pioneers of care, perceive workplace incivility and the factors that affect incivility. And the study was carried out in cross-sectional.

\section{Research Questions:}

- How do nurses perceive workplace incivility?

- What are the factors affecting the perceived workplace incivility of nurses?

Sample: The study was conducted in a state hospital. The population of the study consisted of all nurses working in the hospital $(n=178)$. All nurses who were available (excluding 15 nurses), were not on leave or sick leave within the study period, and were accepted to participate $(n=163)$ were included in the study plan between July and August 2019 . 
Data Collection: The data were collected using a questionnaire containing socio-demographic features form and the Nursing Incivility Scale (NIS). Data were collected in a state hospital between July and August 2019.

Socio-demographic Features Form: This form was prepared by the researchers. It includes 11 questions on age, gender, marital status, educational status, where childhood spent, unit, position, working status, vocational working time, love the profession and willingly choose to nursing.

Nursing Incivility Scale (NIS): The scale has been transformed into a nursing profession-specific in the US by Guidroz et al. (Guidroz, Burnfield-Geimer, Clark, Schwetschenau \& Jex, 2010). The scale is a 5-point Likert type (1 = Certainly disagree, 2 = Disagree, 3 = Neither agree or disagree, 4 = Agree, 5 = Strongly agree) scale and includes five sub-dimensions (nurses in my service, patients/visitors, my first manager, doctors and general incivility) and 43 items. 43 points as the lowest and 215 points as the highest can be obtained from the scale. The Cronbach $\alpha$ reliability coefficient of the original scale subfactors was found to be $\alpha=0.81$ to 0.94 . The increase in the score obtained from the scale indicates that the perception of incivility is high. Turkish validity and reliability of the Nursing Incivility Scale was conducted by Bolat and Özmen (Bolat \& Özmen, 2019). Regarding the reliability of this data-collection instrument, Özmen and Bolat reports a Cronbach's alpha value of 0,94 .

Data Analysis: The evaluation of the data was made in the IBM Statistical Package for the Social Sciences (IBM SPSS Corp.; Armonk, NY, USA) version 23 packet program. Descriptive statistics (mean, standard deviation, median, frequency, minimum, and maximum) related to the variables were calculated. Non parametric tests were used for data not showing normal distribution. Mann-Whitney $U$ test in the two-group comparison and Kruskal-Wallis test was used in the comparison of three or more groups. Significance was evaluated at $p<0.01$ and $p<0.05$ levels.

Ethical Considerations: The study was initiated after receiving the approval of a state university, Faculty Medicine Clinical Research Ethics Committee, and the getting the institution's permission. Informed written consent was obtained from all participants. The Helsinki Declaration Principles were followed. Ethics committee permission was obtained (approval number: 2019-233). 


\section{Results}

Table 1. Demographic characteristics of the nurses ( $N: 163)$

\begin{tabular}{|c|c|c|c|}
\hline & Characteristics & $\mathbf{n}$ & $\%$ \\
\hline \multirow{3}{*}{ Age } & Between $23-30$ years & 65 & 39,9 \\
\hline & Between 31 - 38 years & 57 & 35,0 \\
\hline & 39 years old and over & 41 & 25,2 \\
\hline \multirow{2}{*}{ Gender } & Women & 133 & 81,6 \\
\hline & Men & 30 & 18,4 \\
\hline \multirow{2}{*}{ Marital status } & Married & 110 & 67,5 \\
\hline & Single & 53 & 32,5 \\
\hline \multirow{4}{*}{ Education level } & Vocational Health Highschool & 9 & 5,5 \\
\hline & Associate Degree & 13 & 8,0 \\
\hline & Bachelor & 127 & 77,9 \\
\hline & Master degree & 14 & 8,6 \\
\hline \multirow{3}{*}{ Where childhood spent } & Village & 24 & 14,7 \\
\hline & Town & 69 & 42,3 \\
\hline & City & 70 & 42,9 \\
\hline \multirow{2}{*}{ Working unit } & Internal Units & 77 & 47,2 \\
\hline & Surgical Units & 86 & 52,8 \\
\hline \multirow{3}{*}{ Position } & Service nurse & 149 & 91,4 \\
\hline & Responsible / nurse manager & 10 & 6,1 \\
\hline & Education / quality nurse & 4 & 2,5 \\
\hline \multirow{3}{*}{ Working status } & Continuous day & 30 & 18,4 \\
\hline & Constant night & 1 & 0,6 \\
\hline & Shift & 132 & 81,0 \\
\hline \multirow{3}{*}{ Vocational working time } & Between $1-10$ years & 96 & 58,9 \\
\hline & Between $11-20$ years & 50 & 30,7 \\
\hline & Between $21-30$ years & 17 & 10,4 \\
\hline \multirow{2}{*}{ Loving profession } & Yes & 145 & 89,0 \\
\hline & No & 18 & 11,0 \\
\hline \multirow{2}{*}{ Willingly choose to nursing } & Yes & 108 & 66,3 \\
\hline & No & 55 & 33,7 \\
\hline
\end{tabular}

$81.6 \%$ of the nurses, whose average age was $33.16 \pm 6.97$, were women, $67.5 \%$ were married, $77.9 \%$ were graduated, $42.9 \%$ spent their childhood in the province, $52 \% 8$ of them work in surgical units, $91.4 \%$ are service nursing, and $81.0 \%$ are working in shifts. It was determined that the majority of nurses with an average working time of $9.96 \pm 7.36$ loved their profession (89\%), and $66.3 \%$ willingly choose to nurse (Table 1 ).

Table 2. Nurses' overall scores of the NIS and sub-dimension

\begin{tabular}{lccc} 
Scale and sub-dimension & M \pm SD & Median & Min-Max Point \\
\hline NIS & $122,45 \pm 17,33$ & 123,00 & $67-173$ \\
Nurses in my service & $25,66 \pm 5,37$ & 25,00 & $11-41$ \\
Patients/visitors & $33,04 \pm 7,15$ & 34,00 & $13-50$ \\
My first manager & $15,87 \pm 4,67$ & 15,00 & $7-35$ \\
Doctors & $22,17 \pm 5,80$ & 21,00 & $9-35$ \\
General incivility & $25,69 \pm 4,65$ & 25,00 & $9-37$ \\
\hline
\end{tabular}

The mean total score of the NIS of the nurses who participated in the study was $122.45 \pm 17.33$, and it was determined that the subscale means the score was $25.66 \pm 5.37$ (nurses in my service), $33.04 \pm 7.15$ (patients/visitors), $15.87 \pm 4,67$ (my first manager), $22.17 \pm 5.80$ (doctors) and $25.69 \pm 4.65$ (general incivility) (Table 2 ). 
Table 3. Comparison of the NIS scores with sociodemographic features

\begin{tabular}{|c|c|c|c|c|c|c|c|}
\hline & Characteristics & $\begin{array}{c}\text { NIS } \\
(\text { Mean } \pm S D)\end{array}$ & $\begin{array}{l}\text { Nurses in } \\
\text { my service } \\
\text { (Mean } \pm S D)\end{array}$ & $\begin{array}{c}\text { Patients/ } \\
\text { visitors } \\
\text { (Mean } \pm S D)\end{array}$ & 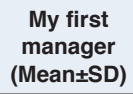 & $\begin{array}{c}\text { Doctors } \\
\text { (Mean } \pm \text { SD) }\end{array}$ & $\begin{array}{c}\text { General } \\
\text { incivility } \\
\text { (Mean } \pm \text { SD) }\end{array}$ \\
\hline \multirow{4}{*}{ Gender } & Women & $121,96 \pm 14,63$ & $25,24 \pm 5,00$ & $32,96 \pm 6,34$ & $16,05 \pm 4,73$ & $22,25 \pm 5,65$ & $25,43 \pm 4,54$ \\
\hline & Men & $124,63 \pm 26,40$ & $27,53 \pm 6,54$ & $33,36 \pm 10,12$ & $15,06 \pm 4,36$ & $21,83 \pm 6,51$ & $26,83 \pm 5,05$ \\
\hline & & $z=-0,535$ & $z=-1,342$ & $z=-0,234$ & $z=-1,385$ & $z=-0,423$ & $z=-1,238$ \\
\hline & & $p=0,592$ & $p=0,180$ & $p=0,815$ & $p=0,166$ & $\mathrm{p}=0,672$ & $p=0,216$ \\
\hline \multirow{4}{*}{ Marital status } & Married & $121,06 \pm 16,49$ & $25,32 \pm 4,84$ & $33,15 \pm 7,04$ & $15,55 \pm 4,32$ & $21,60 \pm 5,56$ & $25,41 \pm 4,45$ \\
\hline & Single & $125,34 \pm 18,77$ & $26,37 \pm 6,32$ & $32,81 \pm 7,45$ & $16,52 \pm 5,31$ & $23,35 \pm 6,16$ & $26,26 \pm 5,05$ \\
\hline & & $z=-1,823$ & $z=-1,020$ & $z=-0,018$ & $z=-1,084$ & $z=-1,942$ & $z=-1,218$ \\
\hline & & $p=0,068$ & $p=0,308$ & $p=0,986$ & $p=0,278$ & $p=0,052$ & $p=0,223$ \\
\hline \multirow{4}{*}{ Working unit } & Internal Units & $124,47 \pm 16,49$ & $25,70 \pm 4,51$ & $35,77 \pm 6,84$ & $16,25 \pm 4,22$ & $21,71 \pm 5,74$ & $25,01 \pm 4,15$ \\
\hline & Surgical Units & $120,65 \pm 17,94$ & $25,63 \pm 6,06$ & $30,59 \pm 6,54$ & $15,52 \pm 5,04$ & $22,59 \pm 5,85$ & $26,30 \pm 5,00$ \\
\hline & & $z=-0,800$ & $z=-0,123$ & $z=-4,640$ & $z=-1,950$ & $z=-0,911$ & $z=-1,797$ \\
\hline & & $p=0,424$ & $p=0,902$ & ${ }^{\star * \star *} p=0,000$ & $p=0,051$ & $p=0,362$ & $p=0,072$ \\
\hline \multirow{4}{*}{ Loving Profession } & Yes & $121,28 \pm 17,28$ & $25,75 \pm 5,59$ & $32,66 \pm 7,09$ & $15,62 \pm 4,58$ & $21,86 \pm 5,42$ & $25,37 \pm 4,62$ \\
\hline & No & $131,89 \pm 15,05$ & $25,00 \pm 3,04$ & $36,11 \pm 7,14$ & $17,83 \pm 5,03$ & $24,66 \pm 8,04$ & $28,27 \pm 4,18$ \\
\hline & & $z=-2,511$ & $z=-0,664$ & $z=-2,063$ & $z=-2,179$ & $z=-1,770$ & $z=-2,548$ \\
\hline & & ${ }^{*} \mathrm{p}=0,012$ & $p=0,507$ & ${ }^{*} p=0,039$ & ${ }^{*} \mathrm{p}=0,029$ & $p=0,077$ & ${ }^{*} p=0,011$ \\
\hline \multirow{4}{*}{$\begin{array}{l}\text { Willingly choose to } \\
\text { nursing }\end{array}$} & Yes & $122,35 \pm 17,32$ & $25,39 \pm 5,70$ & $33,60 \pm 6,79$ & $15,83 \pm 4,75$ & $22,18 \pm 5,59$ & $25,33 \pm 4,61$ \\
\hline & No & $122,65 \pm 17,51$ & $26,20 \pm 4,66$ & $31,94 \pm 7,76$ & $15,94 \pm 4,54$ & $22,16 \pm 6,25$ & $26,40 \pm 4,70$ \\
\hline & & $z=-0,506$ & $z=-1,021$ & $z=-0,996$ & $z=-0,559$ & $z=-0,225$ & $z=-1,293$ \\
\hline & & $p=0,613$ & $\mathrm{p}=0,307$ & $p=0,319$ & $p=0,576$ & $p=0,822$ & $p=0,196$ \\
\hline \multirow{5}{*}{ Age } & Between $23-30$ years & $121,37 \pm 18,22$ & $25,26 \pm 5,69$ & $33,13 \pm 6,65$ & $15,33 \pm 3,95$ & $22,36 \pm 6,49$ & $25,26 \pm 5,05$ \\
\hline & Between 31 - 38 years & $124,51 \pm 18,81$ & $26,17 \pm 5,93$ & $32,56 \pm 6,93$ & $16,59 \pm 6,22$ & $22,84 \pm 5,69$ & $26,33 \pm 4,08$ \\
\hline & 39 years old and over & $121,32 \pm 13,43$ & $25,60 \pm 3,87$ & $33,56 \pm 8,27$ & $15,70 \pm 2,81$ & $20,95 \pm 4,62$ & $25,48 \pm 4,75$ \\
\hline & & $x^{2}=1,213$ & $x^{2}=0,875$ & $x^{2}=0,481$ & $x^{2}=0,036$ & $x^{2}=2,517$ & $x^{2}=1,098$ \\
\hline & & $p=0,545$ & $p=0,646$ & $p=0,786$ & $\mathrm{p}=0,982$ & $p=0,284$ & $p=0,577$ \\
\hline \multirow{5}{*}{$\begin{array}{l}\text { Where childhood } \\
\text { spent }\end{array}$} & Village & $115,67 \pm 20,19$ & $24,83 \pm 4,86$ & $31,29 \pm 8,42$ & $15,00 \pm 3,69$ & $21,20 \pm 6,33$ & $23,33 \pm 5,69$ \\
\hline & Town & $124,72 \pm 16,94$ & $26,37 \pm 4,73$ & $34,07 \pm 7,11$ & $15,82 \pm 4,01$ & $22,23 \pm 5,81$ & $26,21 \pm 4,59$ \\
\hline & City & $122,54 \pm 16,28$ & $25,25 \pm 6,07$ & $32,62 \pm 6,66$ & $16,21 \pm 5,51$ & $22,45 \pm 5,65$ & $25,98 \pm 4,12$ \\
\hline & & $x^{2}=1,562$ & $x^{2}=2,024$ & $x^{2}=2,547$ & $x^{2}=0,159$ & $x^{2}=1,038$ & $x^{2}=6,550$ \\
\hline & & $p=0,458$ & $p=0,364$ & $p=0,280$ & $p=0,923$ & $\mathrm{p}=0,595$ & ${ }^{*} \mathrm{p}=0,038$ \\
\hline \multirow{5}{*}{ Position } & Service nurse & $123,17 \pm 17,17$ & $25,77 \pm 5,39$ & $33,44 \pm 6,71$ & $16,00 \pm 4,72$ & $22,28 \pm 5,83$ & $25,65 \pm 4,62$ \\
\hline & Responsible/manager & $113,30 \pm 17,14$ & $23,80 \pm 5,69$ & $28,40 \pm 11,18$ & $14,10 \pm 4,35$ & $20,70 \pm 5,75$ & $26,30 \pm 5,55$ \\
\hline & Education / quality nurse & $118,75 \pm 21,76$ & $26,50 \pm 3,87$ & $29,75 \pm 8,42$ & $15,25 \pm 2,62$ & $21,75 \pm 5,56$ & $25,50 \pm 4,65$ \\
\hline & & $x^{2}=2,162$ & $x^{2}=0,293$ & $x^{2}=4,094$ & $x^{2}=0,881$ & $x^{2}=0,836$ & $x^{2}=0,105$ \\
\hline & & $p=0,339$ & $p=0,864$ & $p=0,129$ & $p=0,644$ & $p=0,658$ & $p=0,949$ \\
\hline \multirow{5}{*}{ Working Status } & Continuous day & $118,20 \pm 20,26$ & $25,06 \pm 4,90$ & $30,46 \pm 8,57$ & $15,96 \pm 4,89$ & $21,36 \pm 4,35$ & $25,33 \pm 6,13$ \\
\hline & Constant night & $134,00 \pm 0,00$ & $25,00 \pm 0,00$ & $50,00 \pm 0,00$ & $18,00 \pm 0,00$ & $20,00 \pm 0,00$ & $21,00 \pm 0,00$ \\
\hline & Shift & $123,33 \pm 16,5$ & $25,81 \pm 5,50$ & $33,50 \pm 6,56$ & $15,83 \pm 4,65$ & $22,37 \pm 6,10$ & $25,81 \pm 4,27$ \\
\hline & & $x^{2}=1,344$ & $x^{2}=0,913$ & $x^{2}=6,097$ & $x^{2}=1,168$ & $x^{2}=0,651$ & $x^{2}=1,324$ \\
\hline & & $p=0,511$ & $p=0,634$ & ${ }^{*} p=0,047$ & $p=0,558$ & $\mathrm{p}=0,722$ & $p=0,516$ \\
\hline \multirow{5}{*}{$\begin{array}{l}\text { Vocational working } \\
\text { time }\end{array}$} & Between $1-10$ years & $122,17 \pm 19,08$ & $25,22 \pm 5,79$ & $33,18 \pm 6,54$ & $15,61 \pm 5,00$ & $22,47 \pm 6,37$ & $25,65 \pm 4,65$ \\
\hline & Between 11-20 years & $123,62 \pm 14,71$ & $26,22 \pm 4,75$ & $33,86 \pm 7,53$ & $16,34 \pm 4,47$ & $22,02 \pm 4,92$ & $25,18 \pm 4,72$ \\
\hline & Between 21-30 years & $120,65 \pm 14,40$ & $26,52 \pm 4,54$ & $29,82 \pm 8,76$ & $15,94 \pm 3,17$ & $20,94 \pm 4,82$ & $27,41 \pm 4,33$ \\
\hline & & $x^{2}=0,282$ & $x^{2}=1,059$ & $x^{2}=4,085$ & $x^{2}=0,267$ & $x^{2}=0,851$ & $x^{2}=4,373$ \\
\hline & & $p=0,869$ & $p=0,589$ & $p=0,130$ & $p=0,875$ & $p=0,653$ & $\mathrm{p}=0,112$ \\
\hline \multirow{6}{*}{ Education level } & Vocational Health Highschool & $127,89 \pm 8,44$ & $24,77 \pm 1,85$ & $33,11 \pm 9,40$ & $16,55 \pm 4,27$ & $25,33 \pm 4,89$ & $28,11 \pm 5,34$ \\
\hline & Associate Degree & $137,85 \pm 16,23$ & $33,15 \pm 6,02$ & $36,38 \pm 6,55$ & $21,61 \pm 7,14$ & $20,46 \pm 4,09$ & $26,23 \pm 3,19$ \\
\hline & Bachelor & $120,42 \pm 16,90$ & $24,98 \pm 4,81$ & $32,75 \pm 6,86$ & $15,31 \pm 3,94$ & $22,12 \pm 5,66$ & $25,23 \pm 4,69$ \\
\hline & Master degree & $123,14 \pm 19,72$ & $25,50 \pm 6,21$ & $32,50 \pm 8,70$ & $15,14 \pm 5,08$ & $22,21 \pm 8,27$ & $27,78 \pm 4,31$ \\
\hline & & $x^{2}=12,696$ & $x^{2}=17,162$ & $x^{2}=2,430$ & $x^{2}=14,548$ & $x^{2}=4,267$ & $x^{2}=6,794$ \\
\hline & & ${ }^{* *} p=0,005$ & ${ }^{* *} \mathrm{p}=0,001$ & $p=0,488$ & ${ }^{\star *} p=0,002$ & $p=0,234$ & $p=0,079$ \\
\hline
\end{tabular}


It was found that age, gender, the place where they spent their childhood, marital status, working position, duration of employment, and status of voluntary selection of professions do not affect the total and sub-dimension scores of NIS ( $p>$ 0.05). It was determined that there was a statistically significant difference between the mean scores of the "education" variable and the NIS total, the nurses in my service and my first manager sub-dimensions, and the mean scores of the associate degree graduates were higher $(p<0.05)$. It was determined that there was a significant difference between the variable "love the profession" and the mean scores of the NIS total, patient/visitor, my first manager, and general incivility, and the mean scores of those who did not like the profession were high $(p<0.05)$. It was found that there was a statistically significant difference between the "the place where they spent their childhood" variable and the mean scores of the NIS sub-incivility dimension, and the mean scores of those who spent their childhood in the district were high ( $p<0.05)$. It was observed that there was a statistically significant difference between the mean scores of variables of "working style" and "unit of working" and the NIS patient/visitor sub-dimension, and the mean scores of those always working at the night and in the internal medicine service were high $(p<0.05)$ (Table 3).

\section{Discussion}

Uncivil attitudes are unpleasant situations that can be encountered in many sections of society, especially in workplaces, which can reduce work efficiency and productivity (Craft et al., 2020; Guo et al., 2020). Workplace incivility is a global problem faced mostly by nurses in healthcare workers (Alquwez, 2020; Razzi \& Bianchi, 2019). In the current study, we aimed to determine how nurses perceive incivility and the factors that affect incivility.

In the current study, it was observed that nurses perceived moderate incivility at a moderate level most according to the total mean score of NIS, and the mean score is the most at patients/visitors sub-dimension (Table 2). As a result of the study conducted by Alshehry et al. with 378 nurses, it was found that the nurses had moderate incivility similar to the current study, and nurses were mostly faced uncivil behaviors by the patients and their relatives (Alshehry et al. ,2019). Similar to the current study, another study with 261 nurses showed that patient and visitor was more uncivil (Alquwez, 2020). In another study, it was determined that the nurses mostly saw the uncivil behaviors from patients and their relatives (Nikstaitis \& Simko, 2014). Unlike the current study, it was determined that the nurses mostly saw the incivility from their managers and colleagues (Verasari \& Hamzah, 2019). In another study with 206 nurses, it was found that they saw the most uncivil attitudes from doctors in Turkey (Işıkay, 2019). Similarly, in another study conducted with nursing students who were trained, it was observed that the doctors mostly showed uncivil attitudes in China (Shen et al., 2020). As can be seen from the studies, the result of our study shows that similar to the literature, nurses frequently encounter incivility. We think that nurses have a lot of dependent workloads as the reason why nurses are exposed to unknowing attitudes by both patient's relatives and doctors.

In our study, it was observed that the NIS scores of those who do not like the nursing profession are significantly higher than those who love the profession (Table 3). Loving the profession, performing the profession by loving is one of the reasons that bring success and happiness (Bakracheva, 2020). Doing a profession by loving and willingly causes one to ignore the obstacles to be encountered in the profession and increase job satisfaction (Martin, 2020). It is seen that individuals who do not like their profession exhibit negative attitudes in most situations they encounter (Stockman, Van Hoye \& da Motta Veiga, 2020). In the current study, we think that nurses who do not like the profession have high perceptions of incivility because they have a constant negative attitude due to not loving the profession.

There are many people with different educational levels in the nursing profession (Ibrahimoğlu, Mersin \& Saray Kılıç, 2019; Van Keer, Fernandez \& Bilsen, 2020). The education level affects the point of view and perception level of the events they face (Dağ \& Baysal, 2017). In a study made with 50 nurses, it was observed that the education levels of nurses affect the incivility scores, and the incivility scores of the associate degree graduate nurses are high. In addition it was found that the scores of the incivility of the associate degree graduates decreased (El-Amrosy, 2019). Similar to the study, in the current study, it was observed that the nurses who graduated from an associate degree had a high average of incivility (Table 3). We think that the nurses who have not completed their undergraduate education have higher perceptions of being incivility due to lesser theoretical training such as some occupational practice and communication skills.

Workplace incivility is frequently observed especially in units where communication with people is higher (Guo et al., 2020; Irum et al., 2020; Sleem \& Seada, 2017; Verasari \& Hamzah, 2019). Patients and their relatives who need help in the field of health are in close communication with healthcare professionals. In a study conducted in the emergency room, where the circulation was very high, it was observed that the majority of the employees faced uncivil attitudes (Cash, White-Mills, Crowe, Rivard \& Panchal, 2019). In another study conducted with 414 nurses, it was found that the most uncivil attitudes 
were encountered in the emergency and intensive care unit (Layne, Anderson \& Henderson, 2019). In our current study, it was observed that nurses working at night shifts and in internal units had a high perception of incivility (Table 3 ). Depending on the result in our study, it can be said that the incivility perception of nurses working in the internal disease units is high due to the presence of patients with chronic diseases and the presence of the relatives who accompany these patients.

\section{Conclusion and Recommendations}

As a result, in the current study, it was determined that the nurses perceived the workplace incivility in the middle level, education, love the profession, the way they work and the unit worked, affect their level of incivility perception. Based on the current study results, to reduce the perceived workplace incivility in nursing;

- For patients/visitors

- Managing inpatient visitor presence,

- Facilitating the hospital process (length of hospital stay, visiting hours),

- To develop a positive perspective towards nurses in the society,

- Increasing the medical knowledge level of the society

- For nurses collugue, manager and doctors

- Organizing communication techniques training seminars in healthcare professionals that all professional groups can participate together,

- Showing the necessary support by Nursing Managers in dealing with the uncivil attitudes that nurses are exposed to,

- Planning in-service training frequently to prevent nurses from showing uncivil attitudes towards each other,

- During the training of all occupational groups in the field of health, it is recommended that the curricula are compulsory for the courses of team spirit, civility, and communication, and the content of the existing courses is increased.

Ethics Committee: Approval was obtained from Sakarya University, Faculty Medicine Clinical Research Ethics Committee (Number: 2019-233).

Conflict of Interest: Not reported.

Funding: None.

Informed Consent: Written informed consents of the participants were obtained.

\section{References}

Alquwez, N. (2020). Examining the influence of workplace incivility on nurses' patient safety competence. Journal of Nursing Scholarship, 0(0), 1-9. https://doi.org/10.1111/jnu.12553

Alshehry, A. S., Alquwez, N., Almazan, J., Namis, I. M. \& Cruz, J. P. (2019). Influence of workplace incivility on the quality of nursing care. Journal of Clinical Nursing, 28, 4582-4594. https://doi.org/10.1111/jocn.15051

Andersen, P., McAllister, M., Kardong-Edgren, S., Miller, C. W. \& Churchouse, C. (2019). Incivility behaviours exhibited by nursing students: Clinical educators' perspectives of challenging teaching and assessment events in clinical practice. Contemporary Nurse, 55(4-5), 303316. https://doi.org/10.1080/10376178.2019.1634480

Bakracheva, M. (2020). The meanings ascribed to happiness, life satisfaction and flourishing. Psychology, 11(1), 87-104. https://doi.org/10.4236/psych.2020.111007

Bambi, S., Guazzini, A., Felippis, C., Lucchini, A. \& Rasero, L. (2017). Preventing workplace incivility, lateral violence and bullying between nurses. A narrative literature review, Original article: Nursing in society and in the workplace. Acta Biomed for Health Professions, 88(5), 39-47. https://doi.org/10.23750/abm.v88i5-S.6838 
Bolat, E. \& Özmen, D. (2019). Turkish validity and reliability study of Nursing Incivility Scale. Journal of Anatolia Nursing and Health Sciences, 22(4), 249-258. https://doi.org/10.17049/ataunihem.454253

Cash, R. E., White-Mills, K., Crowe, R. P., Rivard, M. K. \& Panchal, A. R., (2019). Workplace incivility among nationally certified ems professionals and associations with workforce-reducing factors and organizational culture. Prehospital Emergency Care, 23(3), 346-355. https://doi.org/10.1080/10903127.2018.1502383

Clark, C. M. (2017). An evidence-based approach to integrate civility, professionalism, and ethical practice into nursing curricula. Nurse Educator, 42(3), 120-126. https://doi.org/10.1097/NNE.0000000000000331

Craft, J., Schivinski, E. L. \& Wright, A. (2020). The grim reality of nursing incivility. Journal for Nurses in Professional Development, 36(1), 41-43. https://doi.org/10.1097/NND.0000000000000599

Dağ, E. \& Baysal, H. (2017). Analysis of factors which lead patients and their relations to violence - the example of the province of Burdur. Eurasian Journal of Researches in Social and Economics, 4(11), 95-118. Retrieved from http://dergipark.org.tr/en/pub/asead/issue/52677/694350

El-Amrosy, S. H., Elkholy, S. M. \& Elshall, S. E. (2019). The effect of educational intervention about incivility on psychological wellbeing and burnout among nurses. American Journal of Nursing, 7(6), 1069-1077. https://doi.org/10.12691/ajnr-7-6-21.

Green, C. A. (2019). Workplace incivility: Nurse leaders as change agents. Nursing Management, 50(1), 51-53. https://doi.org/10.1097/01.NUMA.0000550455.99449.6b

Guidroz, A. M., Burnfield-Geimer, J. L., Clark, O., Schwetschenau, H. M. \& Jex, S. M. (2010). The nursing incivility scale: Development and validation of an occupation-specific measure. Journal of Nursing Measurement, 18(3), 176-200. https://doi.org/10.1891/1061-3749.18.3.176

Guo, J., Qiu, Y. \& Gan, Y. (2020). Workplace incivility and work engagement: The chain mediating effects of perceived insider status, affective organizational commitment and organizational identification. Current Psychology, 1-12. https://doi.org/10.1007/s12144-020-00699-z

Irum, A., Ghosh, K. \& Pandey, A. (2020). Workplace incivility and knowledge hiding: A research agenda. Benchmarking: An International Journal.( BIJ), 27(3),958-980. doi 10.1108/BIJ-05-2019-0213

Işıkay, Ç. (2019). The relationship between workplace incivility and demographic features: A study on nurses. International Journal of Health Management and Strategies Research, 5(1), 51 -68. http://dx.doi.org/10.17719/jisr.2019.3299

İbrahimoğlu, Ö., Mersin, S. \& Saray Kılıç, H. (2019). Nursing education curriculum and learning outcomes. Journal of Higher Education \& Science, 9(1),12-16. https://doi.org/10.5961/jhes.2019.305

Layne, D. M., Anderson, E. \& Henderson, S. (2019). Examining the presence and sources of incivility within nursing. Journal of Nursing Management, 27,1505-1511. https ://doi.org/10.1111/jonm.12836

Martin, J. (2020). Job satisfaction of professional librarians and library staff. Journal of Library Administration, 1-18. https://doi.org/10.1080/01930826.2020.1721941

Meier, L. L. \& Semmer, N. K. (2013). Lack of reciprocity, narcissism, anger, and instigated workplace incivility: A moderated mediation model. European Journal of Work and Organizational Psychology, 22(4), 461-475. https://doi.org/10.1080/1359432X.2012.654605

Nikstaitis, T. \& Simko, L. C. (2014). Incivility among intensive care nurses: The effects of an educational intervention. Dimensions of Critical Care Nursing, 33(5), 293-301. https://doi.org/10.1097/DCC.000000000000006

Pearson, C. (2010). The cost of bad behavior, how incivility is damaging your business and what to do about it. Human Resource Management International Digest, 18(6). https://doi.org/10.1108/hrmid.2010.04418fae.002

Porath, C. L. \& Pearson, C. M. (2012). Emotional and behavioral responses to workplace incivility and the impact of hierarchical status. Journal of Applied Social Psychology, 42, E326-E357. https://doi.org/10.1111/j.1559-1816.2012.01020.x 
Razzi, C. C. \& Bianchi, A. L. (2019, October). Incivility in nursing: Implementing a quality improvement program utilizing cognitive rehearsal training. Nursing Forum, 54(4), 526-536. https://doi.org/10.1111/nuf.12366

Samson-Mojares, R. A., Chin, C. R., Colvin, M. K. \& Umadhay, T. (2019). Where do you think you are? A grounded theory study of the critical factors triggering the existence and fueling the persistence of incivility in nursing. Nursing Education Perspectives, 40(3), 133-138. https://doi.org/10.1097/01.NEP.0000000000000397

Schoville, R. \& Aebersold, M. (2020). How workplace bullying and incivility impacts patient safety: A qualitative simulation study using BSN students. Clinical Simulation in Nursing, Vol(X), 1-8. https://doi.org/10.1016/j.ecns.2020.01.003.

Shen, H., Wang, H., Yan, L., Liu, W., Zhang, J., Zhou, F. \& Deng, L. (2020). Incivility in nursing practice education in the operating room. Nurse Education Today, 88, 104366. https://doi.org/10.1016/j.nedt.2020.104366

Sleem, W. F. \& Seada, A. M. (2017). Role of workplace civility climate and workgroup norms on incidence of incivility behaviour among staff nurses. International Journal of Nursing Didactics, 7(06), 34-43. http://dx.doi.org/10.15520/ijnd.2017.vol7.iss6.230.34-43

Stockman, S., Van Hoye, G. \& da Motta Veiga, S. (2020). Negative word-of-mouth and applicant attraction: The role of employer brand equity. Journal of Vocational Behavior, 118, 103368. https://doi.org/10.1016/j.jvb.2019.103368

Torkelson, E., Holm, K., Bäckström, M. \& Schad, E. (2016). Factors contributing to the perpetration of workplace incivility: The importance of organizational aspects and experiencing incivility from others. Work \& Stress, 30(2), 115-131. https://doi.org/10.1080/02678373.2016.1175524

Tricahyadinata, I., Hendryadi, S., Zainurossalamia Z. A. S. \& Riadi, S. S. (2020). Workplace incivility, work engagement, and turnover intentions: Multi-group analysis. Cogent Psychology, 7(1), 1743627. https://doi.org/10.1080/23311908.2020.1743627

Van Keer, R. L., Fernandez, S. M. \& Bilsen, J. (2020). Intercultural mediators in Belgian hospitals: Demographic and professional characteristics and work experiences. Patient Education and Counseling, 103(1), 165-172. https://doi.org/10.1016/j.pec.2019.07.021

Verasari, M. \& Hamzah, H. (2019). The effect of experienced incivility from supervisor and coworkers towards insitgated incivility in daily level among nurses. International Journal for Educational and Vocational Studies, 1(4), 359-363. https://doi.org/10.29103/ijevs.v1i4.1781

Woo, C. H. \& Kim, C. (2020). Impact of workplace incivility on compassion competence of Korean nurses: Moderating effect of psychological capital. Journal of Nursing Management, 00, 1-8. https://doi.org/10.1111/jonm.12982

Zhou, Z. E., Yan, Y., Che, X. X. \& Meier, L. L. (2015). Effect of workplace incivility on end-of-work negative affect: Examining individual and organizational moderators in a daily diary study. Journal of Occupational Health Psychology, 20(1), 117. https://doi.org/10.1037/a0038167 